\title{
Clare Balding: the televisual face of London 2012
}

Article

Accepted Version

Woods, F. (2013) Clare Balding: the televisual face of London 2012. Journal of Popular Television, 1 (1). pp. 137-141. ISSN 2046-9861 doi: https://doi.org/10.1386/jptv.1.1.137_1 Available at https://centaur.reading.ac.uk/33186/

It is advisable to refer to the publisher's version if you intend to cite from the work. See Guidance on citing.

Published version at:

http://www.ingentaconnect.com/content/intellect/jptv/2013/00000001/00000001/art00013;jsessionid=c9daen58eg90k.a lexandra

To link to this article DOI: http://dx.doi.org/10.1386/jptv.1.1.137_1

Publisher: Intellect

All outputs in CentAUR are protected by Intellectual Property Rights law, including copyright law. Copyright and IPR is retained by the creators or other copyright holders. Terms and conditions for use of this material are defined in the End User Agreement.

\section{www.reading.ac.uk/centaur}

\section{CentAUR}

Central Archive at the University of Reading

Reading's research outputs online 


\title{
Clare Balding: the televisual face of London 2012
}

Faye Woods (University of Reading)

Department of Film, Theatre \& Television

University of Reading

Minghella Building

Whiteknights

Reading RG6 6BT

UK.

E-mail: f.woods@reading.ac.uk

\section{Biography}

Faye Woods is Lecturer in Film and Television at the University of Reading, United Kingdom. Her research interests include popular music in film and television, youth representations, television industries and gender. She has published on popular music in teen television, the relationship between British and US teen television and the teen dance film.

\begin{abstract}
This piece discusses the performance of television presenter Claire Balding during her coverage of the Olympics and Paralympics of London 2012. It suggests that her success with viewers was connected with her persona as a television personality, which combined professional skill with intimacy and immediacy. It argues that Balding represented the face of contemporary public service broadcasting - one that bridges both the BBC and Channel 4's brand identities - through her research and authority, combined with interaction with her audience with social media.
\end{abstract}

\section{Keywords}

television personality, Olympics, presenter, public service broadcasting, gender, sport

Who was Britain's star of London 2012? Was it Mo Farah or Jessica Ennis on Super

Saturday in the Olympic Stadium? ${ }^{\mathrm{i}}$ Was it Kath Grainger finally rowing to gold at her fourth attempt? Was it David Weir or Sarah Storey with their brace of Paralympic golds? I wish to make the case for broadcaster Clare Balding, who featured across the BBC's Olympic and Channel 4's Paralympic coverage. Post-Olympics Balding was elevated to the status of national treasure (Lee 2012), and received plaudits across the press and social media, from broadsheets to celebrity gossip magazines. The Telegraph marked her presenting 10 out of 10 (Duncan 2012), whilst Heat magazine named her 'the newly anointed grande dame of British TV' (Crothers 2012) and even abrasive Daily Mail columnist Jan Moir praised her 'natural 
empathy and curiosity' (Moir 2012). Balding gained 100,000 new Twitter followers over London 2012 and where Conservative politicians were pelted with boos when presenting flowers to Paralympic medalists at the Olympic Stadium, Balding received raucous cheers and a standing ovation. So why was London 2012 Balding's moment? Why did a slightly posh lesbian, nearing middle age with a sensible haircut turn out to be the viewers' darling?

I suggest that London 2012 saw Balding's status move from broadcaster - a highly experienced presenter of live events and sports - to 'television personality'. Her success can be connected to the key discourses surrounding television personality as identified by James Bennett: ordinariness, authenticity, intimacy and work (including skill) (Bennett 2011: 26). I also argue that she can be seen to personify contemporary public service broadcasting bridging both BBC and Channel 4 versions - whilst also reflecting Britain's own experience of London 2012 and the gendered narrative of the Games.

Popular discourse shaped London 2012 as the 'Women's Olympics'. With the introduction of women's boxing allowing gender parity across all sports and every country fielding female athletes for the first time, London 2012 was framed by officials and press coverage as the first 'equal' Olympics. Team GB's first medal (a silver) and its first gold went to women - in the cycling road race and paired rowing sculls respectively - and women out-medalled men for the United States, China and Russia (Jenkins 2012). This was a Games where women's achievements were the central narrative, with The Observer asking whether this was 'a breakthrough year for Olympic girl power' (The Observer 2012). Balding herself contributed to this discourse, highlighting female sporting achievements throughout her coverage. Female presenters emerged as the successes of the BBC's Olympic coverage with Gabby Logan, Denise Lewis, Hazel Irvine and Balding in particular gaining plaudits (Wallop 2012). The success of a veteran female sports broadcaster - aged 41, Balding has covered five Olympics and a myriad of live and sporting events - was also significant for a BBC 
recently under fire over a lack of women on-screen and particularly its sidelining of mature female presenters (Revoir 2012).

Balding's main BBC role was to anchor from Olympic venues and she was primarily based at the Aquatics Centre and the Greenwich Equestrian Arena. Here she framed and contextualized the sporting action, discussing events with pundits, competitors and parents. She also worked to communicate the intensity of the sporting and spectating experience. Whilst the main anchors were encased in the BBC's glass box studio overlooking the Olympic Park, distanced from the crowds, Balding - like others at venues - not only reported on events but also the crowd's response, the physicality of their noise. Both the Olympic and Paralympic coverage focused significantly on the experience of spectating, the feeling and emotion of being there. The crowd's role in roaring the competitors to victory was highlighted; every post-race interview asked a variation on 'What was the effect of this crowd?' That medal, it was inferred, partly belonged to the British public.

Intensity of emotion was central to the experience of London 2012. Notably two of the most heavily circulated viral videos from the BBC's coverage were of visceral emotional responses to sport. The off-camera footage of the BBC athletics pundit team - including the usually immaculate and refined Denise Lewis - showing them screaming Mo Farah to victory on Super Saturday (Duncan 2012) pictured 'authentic' emotion cutting through professionalism. Balding's interview with Bert Le Clos, father of South African 100m freestyle gold medallist Chad Le Clos (Burke 2012) helped to signify both her televisual skill and her authenticity. As Bennett notes: 'the presence of ordinary people emphasizes the sense of immediacy, spontaneity and revelation of the essential self in televisual performance: as an element in the production that the television personality is not entirely in control of' (Bennett 2011: 129). As the effusive, red-faced bearded man let out a muddled stream of joy and emotion, his generous belly straining at his shirt, Balding shifted between gently attempting 
to guide him and sitting back and succumbing to his enthusiasm. The moment illustrated Balding's ability to embrace spontaneity and enthusiasm yet remain in control - defining traits of her broadcasting performance.

It also showcased her televisual skill (Bennett 2011) as an interviewer, which combined with another Balding key trait - her inquisitiveness - in her probing of swimming pundits and ex-Olympians Mark Foster and Ian Thorpe for analysis and information at the pool. Balding delighted in Thorpe's detailed technical analysis and strong opinions whilst her innate warmth drew out a relaxed, cheeky camaraderie in marked contrast to the awkward tension Thorpe displayed on the BBC studio sofa when faced with the forced banter and under-researched questions of Gary Lineker. At Greenwich, Balding's equestrian background and experience as a horse-racing broadcaster allowed her to play both presenter and pundit. Here she was able to combine her televisual skills with her vocational skills (Bennett 2011), as she delightedly rattled off a ream of information to camera, framing the historic nature of Team GB's gold medal for a television audience largely unfamiliar with the sport.

Balding's balance of excitement and professional control can be seen as representative of the BBC's coverage as a whole, which was lauded for its comprehensive depth (two channels broadcasting throughout the day with up to 24 simultaneous live sports feeds) with its ability to reflect the national mood. Her passion for and delight in London 2012 made her transparent, connected her with the audience at home and made her 'ordinary' - hallmarks of Bennett's television personality (2011). Compared to Lineker's strained attempts at jocular charm or John Inverdale's distanced dryness, Balding reflected the surprised joy of Britain, the sincerity with which the country seemed to embrace the Games and leave its cynicism aside for a few weeks.

Balding moved over to Channel 4 for the Paralympics where she became the slightly quirky elder stateswoman of a more youthful team, anchoring the evening coverage with ex- 
Paralympian Ade Adepitane. Her presence created continuities yet highlighted differences between the broadcasters. Channel 4 paired experienced sports broadcasters with younger disabled presenters and centralized the studio anchors, who framed a flow of live coverage and highlights, engaging in substantial discussion with studio pundits. Perhaps a necessity for an audience unfamiliar with Paralympic sports and classifications, the format reduced the immediacy of the viewing experience and distanced Balding from the sporting action. In contrast with her relatively casual BBC appearance she was clad in sharp jackets and glamorous make-up. Yet she was quick to inform viewers that she was wearing jeans and trainers under her dress, undermining the normative feminine glamour and asserting her down-to-earth 'true self'. Balding's authenticity could be problematized by her privileged background - she was head girl at her elite private school, has aristocratic relatives and mixed with (and rode against as an amateur jockey) royalty. However, this identity is complicated by her sexuality; as one of British media's few 'out' lesbians she is enough of an outsider to fit comfortably into the quirky, slightly edgy channel identity of Channel 4.

Whether anchoring from studio or venue Balding was accompanied by two artefacts that are key to her identity as a television personality, the notebook and piles of paper that inevitably sit in front of her, and the smart phone or iPad that joins them - the portal to social media. The former signifies her research and preparation - in contrast to other presenters' single scripts - and acts as a marker of transparency: she does not conceal the work put into each broadcast. Her repeated motto 'Facts are my friend' displayed both her inquisitiveness her desire to flesh out and personalize coverage with an interesting detail or story - and the safety net needed for a successful live broadcaster. The latter demonstrates how London 2012 was framed by both the BBC and Channel 4 as an interactive, multiplatform experience, foregrounding online coverage and social media (Bell 2012). Presenters brandished iPads, fielding queries and comments - often awkwardly - from Twitter as coverage unfolded. A 
keen Twitter user, the platform allowed Balding's enthusiasm for the Games to expand beyond her on-screen role. Whether tweeting diving scores when the BBC's coverage was focused on the Olympic Stadium, where she fielded questions and provided amateur commentary or when eagerly tweeting pictures of excited international Paralympians as they waited to join the Opening Ceremony, Balding made herself a multiplatform interpreter of the Olympics experience.

All of these elements can be drawn together to conclude that Balding is an ideal representative of contemporary public service broadcasting. Bennett (2011: 122) notes that 'certain personalities' televisual images are deemed able to carry the institutional voice of a public service organisation through evoking Reithian edicts of "inform, educate and entertain" - in that order'. Balding's professionalism and research conveys authority and knowledge, yet she interacts freely with her audience through the intimacy and immediacy of social media. In fact, as a slightly mature woman, a touch posh, whom we trust to inform and guide us, and view with a fondness, it could be said that Clare Balding is Auntie Beeb. Her presence - carrying the afterglow of her successful Olympics with the BBC - helped legitimize the public service standing of Channel 4's Paralympics coverage after the widespread criticism of its coverage of the 2011 Athletics World Championships (Plunkett 2011). Balding's class status and her televisual skills provide her with authority yet her warmth and accessibility mark her as the face of interactive, viewer-focused contemporary public service broadcasting.

\section{References}

Bell, E. (2012), 'Lessons to be learned from the first social media Olympics', The Guardian, 5 August, http://www.guardian.co.uk/media/2012/aug/05/lessons-learned-socialmedia-olympics. Accessed 24 September 2012.

Bennett, J. (2011), Television Personalities: Stardom and the Small Screen, Abingdon: Routledge. 
Burke, T. (2012), 'This BBC interview with Chad Le Clos's father is the media moment of the games so far', Deadspin, 31 July, http://deadspin.com/5930604/this-bbcinterview-with-chad-le-closs-father-is-the-media-moment-of-the-games-so-far. Accessed 24 September 2012.

Christenson, M. (2012), 'London 2012: "A gold rush for eternity" - how the world saw Super Saturday', The Guardian, 5 August, http://www.guardian.co.uk/sport/2012/aug/05/london-2012-britain-super-saturday. Accessed 24 October 2012.

Crothers, J. (2012), “'I didn't realise I had iconic hair!”: The Heat interview - Clare Balding', Heat, 695 (1 September), pp. 66-70.

Duncan, H. (2012), 'BBC pundits in amazing reaction to capture the mood of the nation', Metro, 5 August, http://www.metro.co.uk/olympics/907519-bbc-pundits-capturemood-of-the-nation-with-golden-mo-farah-reaction. Accessed 24 September 2012.

Jenkins, S. (2012), 'Women's Olympic success: a flood that began as a trickle', Washington Post, 12 August, http://www.washingtonpost.com/sports/olympics/womens-olympicsuccess-a-flood-that-began-as-a-trickle/2012/08/12/2799c9ba-e4a2-11e1-8f6258260e3940a0_story.html. Accessed 24 September 2012.

Lee, V. (2012), 'Clare Balding: "National treasure? That's not me"”, The Independent, 16 September, http://www.independent.co.uk/news/people/profiles/clare-baldingnational-treasure-thats-not-me-8142463.html. Accessed 24 September 2012.

Moir, J. (2012), 'Jan Moir - View from the sofa: Why can’t everyone be Clare Balding?, Daily Mail, 2 August, http://www.dailymail.co.uk/news/article-2182378/London2012-Olympics-Why-Clare-Balding.html. Accessed 24 September 2012.

Plunkett, J. (2011), 'Channel 4 drops Ortis Deley as main athletics presenter', The Guardian, 31 August, http://www.guardian.co.uk/media/2011/aug/31/ortis-deley-channel-4. Accessed 25 September 2012.

Revoir, P. (2012), 'I got it wrong on older women: BBC boss admits there ARE too few on TV', Daily Mail, 9 February, http://www.dailymail.co.uk/news/article-2098498/I-gotwrong-older-women-BBC-boss-admits-ARE-TV.html (Accessed 24 September 2012).

The Observer (2012), "Olympics for the girls..." How Team GB fell in love with its feminine side', The Guardian, 4 August, http://www.guardian.co.uk/sport/2012/aug/04/london-2012-women-beat-men-medals. Accessed 24 September 2012.

Wallop, H. (2012), 'And the gold medal for presenting goes to ...', The Telegraph, 3 August, http://www.telegraph.co.uk/culture/tvandradio/tv-and-radio-reviews/9449709/Andthe-gold-medal-for-presenting-goes-to-....html. Accessed 24 September 2012. 
${ }^{i}$ Saturday 4 August 2012 was christened 'Super Saturday' by the media after Great Britain won six gold medals in one day, including three in the space of an hour in the evening session at the Olympic Stadium (Christenson 2012). 